\title{
COVID-19, Digital Tracking Control and Chinese Cosmotechnology
}

\author{
Jana S. ROŠKER*
}

\begin{abstract}
The COVID-19 pandemic has opened our eyes to numerous global problems that can only be solved on a global scale. Especially in light of the good performance of the Sinic region in containing and eliminating the coronavirus, the importance of intercultural dialogue between East and West became even more evident. In this context, this paper explores the role of digital technologies and the underlying ontology of digital objects in China as well as in the wider Sinic region. Indeed, the third millennium, which has just begun and will witness the accelerating trends of global warming and most likely the deepening of the gap between rich and poor, numerous wars, and new pandemics, will certainly be marked by the development of digital technologies. Therefore, the paper investigates the specific features of traditional Sinic perceptions of technology as such, as well as their ideational underpinnings, which certainly influence specific Sinic perceptions of digital objects. This will, I hope, provide us with a better understanding of the cultural conditionality of differences and commonalities in the global processes of digitalization and their ontological underpinnings, so that we can pay more attention to both the dangers and the opportunities that cross-cultural interactions in this area can offer us.
\end{abstract}

Keywords: digital technology, ontology of digital objects, China and the Sinic region, COVID-19

\section{COVID-19, digitalno upravljani nadzor in kitajska kozmotehnologija}

\section{Izvleček}

Pandemija COVID-19 je pokazala na številne globalne probleme, ki jih lahko rešimo samo na globalni ravni. Zlasti v luči dobrih rezultatov siniške regije pri zajezitvi in odpravljanju koronavirusa je postal pomen medkulturnega dialoga med »vzhodom « in »zahodom« še toliko bolj jasen. V tem okviru se pričujoči članek osredotoča na raziskavo vloge digitalnih tehnologij in ontologije, na kateri temeljijo digitalni objekti na Kitajskem, pa tudi v širši siniški regiji. Tretje tisočletje, ki se je šele dobro začelo in v katerem bomo soočeni z vse hujšimi posledicami globalnega segrevanja, s poglabljanjem brezna med bogatimi in revnimi, s številnimi vojnami in novimi pandemijami, bo namreč hkrati

Jana S. ROŠKER, Professor of Sinology, Department of Asian Studies, Faculty of Arts, University of Ljubljana, Slovenia.

Email address: jana.rosker@ff.uni-lj.si

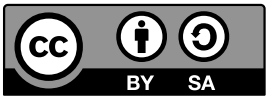


zaznamovano $\mathrm{z}$ razvojem digitalnih tehnologij. Zato avtorica raziskuje specifične značilnosti tradicionalnega siniškega dojemanja tehnologije kot take ter njenih idejnih osnov, ki zagotovo vplivajo na specifično percepcijo digitalnih objektov v siniški regiji. Avtorica upa, da nam bo to omogočilo boljši vpogled $\mathrm{v}$ kulturno pogojenost razlik in podobnosti $\mathrm{v}$ globalnih procesih digitalizacije in njenih ontoloških osnov, kajti tak uvid nam lahko omogoči tudi boljše razumevanje nevarnosti in možnosti, ki se kažejo v medkulturnih interakcijah na tem področju.

Ključne besede: digitalna tehnologija, ontologija digitalnih objektov, Kitajska in siniška regija, COVID-19

\section{Introduction}

The high efficiency in containing and partially eliminating the COVID-19 pandemic in the Sinic ${ }^{1}$ geopolitical area was often attributed to the autocratic traditions of this region. Numerous Western media reported that because of such traditions the Sinic population was more obedient and less critical, which allowed governments to implement repressive top-down measures more easily than in the West.

As I have shown elsewhere (see Rošker 2021, 67), such assumptions are populist, unfounded, and unscientific, and the instead reasons for this greater efficiency in combatting COVID-19 are most likely related to traditional Confucian relational ethics.

An additional problem often highlighted in the context of COVID-19 is that of digital control of individuals in Sinic cultures based on databases of personal information, which allow for rapid and efficient control of infected individuals, their appropriate treatment and isolation. These are measures that cannot be similarly implemented in Western societies for the time being, not only because of the legal requirements for the protection of personal data, but also because of the corresponding attitudes of their citizens, who would most likely resist most such actions. On the other hand, empirical studies have shown that the majority of people in the East Asian region were convinced that their societies could achieve freedom for the community as a whole by individuals giving up-at least in part— their private, individual liberties (Bauer 2020, 8).

1 This is the region that has historically been heavily influenced by Chinese writing and certain cultural elements that originated in China, particularly Confucianism and Chan (Zen) Buddhism. Besides China itself, the area includes Korea, Japan, Taiwan and Hong Kong, but also some parts of Southeastern Asia, such as Vietnam, Laos and Singapore. 
The enactment of compulsory "social distancing" and strict isolation measures was backed up in many European states not only with fines and similar disciplinary measures, but also with restrictions that in some cases came close to violating the constitutional order. Particularly problematic were such measures that imposed curfews, closed not only inter-state but also local borders between different regions of the same state, or banned gatherings of large numbers of people, even if they wanted to exercise a fundamental right of democratic societies by protesting the political decisions of their governments. Many people were concerned that traditional Enlightenment values-such as freedom and autonomy-would succumb in this way to the pressures of new "corona dictatorships", a phenomenon that is becoming increasingly problematic, especially in some Central and East European countries (Buras 2020). Nonetheless, many Europeans expressed concern about the supposedly autocratic methods of digital control that are spreading in the wake of anti-pandemic measures in the Sinic regions, but also in many other areas of Asia and Russia. In this context, the assumptions about the "totalitarian character" of Sinic societies noted above have been constantly repeated. Therefore, in order to gain a more realistic insight into the current situation, it seems necessary to shed light on the complex relationship between traditional forms of social control and contemporary measures of disease control in the Sinic region. This paper attempts to illuminate this relationship from the perspective of the specifically Sinic understanding of digital objects and through the lens of classical Chinese cosmotechnology.

\section{Digital Tracking Measures in the Sinic Region: Traditional Backgrounds and Contemporary Implications}

While the countries of the Euro-American regions continued to adhere to physical distancing and the closure of public spaces not vital to the functioning of society during the second wave of the epidemic, the societies of the Sinic region relied heavily on the mass use of digital applications to combat the pandemic. In various publications, East Asian authors ask whether COVID-19 could not be a signal for a general reflection on how we can achieve a balance between privacy on the one hand and the public sphere on the other ${ }^{3}$ (Huang, Sun in Sui 2020). The emphasis on the protection of privacy in the process of combating pandemics, as we

2 This term has been used frequently in the Western media, see, for example, BBC News 2020.

3 At the time of writing, a number of Western countries have also begun to develop digital applications that, on the one hand, allow the tracking of contacts, but on the other also preserve the anonymity of users and limit the amount of data collected. 
are witnessing in the Euro-American area, obviously affects not only the decisions of the populations of Western countries, but also the relevant legislation, since a number of measures that could be implemented in East Asia could not be realized in Europe, as they would violate many legal provisions on the protection of personal data. ${ }^{4}$ With this in mind, it is also important to reassure people that such data would be deleted from digital databases once the pandemic is over.

Digital control applications, which are part of pandemic containment measures in many Sinic countries, typically work as follows: When a particular person tests positive, their phone number is sent to the local police station, which sends a digital application to collect all the data about the infected person to the centre for Personal Data Collection. The smartphone data shows the locations where the person has been in the last few days. The items in these places are sanitized by the crisis centre staff, who also contact all the people who have been in these places at these times; to do this, they can use bank data from credit and other payment cards that show who has paid bills in the same restaurants and other places the infected person has been, or who has used the same bus lines. In this way, they try to get as complete a list as possible of people who have been in contact with, or at least near, the infected person. These people are then contacted by the medical centre, which calls them in for tests and at the same time sends them into self-isolation.

With all the heated discussions around the complex issues of digital control of individuals in times of crisis, which confront us with moral and ethical dilemmas about what is more important, human life and societal security or individual liberty, it is good to also reflect on how technologies of digital control-like any other technology — can be used for both beneficial and harmful purposes. It is the free and critical humanities, with their underlying humanistic values, that bear the greatest responsibility in this regard. The only guarantee that digital control technologies will be used in a way that helps to preserve human life and, in the long term, also to protect fundamental human rights and freedoms, is firm and stable, but also flexible, legislation and ethics that protect the values of interpersonal responsibility, solidarity and cooperation, and the fundamental freedom and dignity of every person.

4 In Sinic societies, large databases often contain a combination of data from many different sources, e.g. banks, medical and automotive databases, security cameras, etc., through the kind of procedures that are strictly forbidden in the EU and US. On the other hand, the critical awareness of the populations in these areas with regard to this issue is not much higher than that of the populations of East Asian countries, considering how generous people are when they enter their personal data on the websites of various social networks and online applications. In most European countries, public health systems also hold data on all physical and biological characteristics of individuals, as well as digital records of their entire medical history with diagnoses and treatments. 
In what follows, I will highlight two very different ways in which the use of digital technology in the contemporary Sinic space has contributed, each in its own way, to the containment of the COVID-19 pandemic. The first is associated with normative ethical behaviour based on the standards of an autocratic ideology, and the second is based on democratic networks of data application. The foundations of both systems can be traced back to Confucian philosophies or ideologies.

The best example of a very problematic form of digital control in East Asia is the infamous “social credit system” (shehui xinyong tixi 社會信用體系) gradually introduced in China since 2020. It is important to see that its historical roots were linked to the traditional power structures based on the model of the family and its hierarchical relations, which underlay Confucian social ideologies. Although classical Confucian relational ethics still has a positive influence on social solidarity, effective cooperation, and mutual empathy, the normative state doctrines developed on the basis of these moral philosophies also provided a solid foundation for a strictly defined framework of normative standards of conduct, which was reinforced by socio-historically shaped mechanisms of social control. These were not only implemented at the various levels of the state and its legislative and executive institutions, but were even more deeply rooted in civic communities themselves. ${ }^{5}$

Similar to today's system of social credit, the system of informal control at the basic local levels of towns and villages, often supported by groups of street overseers, had an eye on the morals and behaviour of individuals. The two systems also share similar mechanisms of propaganda; throughout Chinese history, the traditional system of control has always been based on state propaganda that monitored and influenced popular culture in a way that reinforced the state ideology. If we understand this traditional combination or fusion of formal and informal control mechanisms and instances, it will be easier for us to grasp the fact that the introduction of the social credit system is supported by the majority of the population at all levels, and especially by educated people (Kostka 2019, 1565). ${ }^{6}$

5 The control mechanisms that prevailed in traditional Chinese (and various Sinic) societies constituted a system or network of formal and informal control instances, the basic cell of which was the family and its organization, based on hierarchy and supported by ideological control functions (Kempter Streib and Streib 1998, 207). In their pure, ideal-typical form, such forms of strict and all-encompassing control were based on certain elements of legalistic doctrine, which were integrated into the new social ideology of Confucianism in the course of the first reform of Confucian teachings in the period of Han Dynasty. Later, this "Confucian" ideology prevailed in China in the form of a state doctrine consisting of a combination of legalistic normativity and Confucian ethical-moral prescriptions or guidelines. Such a normative ideology could function both at the official formal level and at the informal level of local community structures.

6 A recent study conducted in China by researchers at the Free University (FU) in Berlin found that as many as $80 \%$ of Chinese informants strongly support the social credit system, while the remaining $19 \%$ of respondents are undecided and only 1\% oppose it (see Hui 2019, 6). 
In Maoist China, too, ideology played a major role in mass mobilizations and power struggles (see Heubel 2019, 39), even if today it seems that it could no longer be a single, central instrument for maintaining social stability. And yet we could argue that the "system of social credits" of the digital control type is a form of technology that is not only based on ideology, but is itself a kind of ideology. This system, which the National Development and Reform Commission (Guojia fazhan he gaige weiyuan hui 国家发展和改革委员会) has been preparing since 2014 and which has been in use throughout China since 2020, is closely related to axiological systems based on ruling ideologies that emphasize the vital importance of social stability and patriotism. It is a digital system of all-encompassing control that employs the latest technologies, including facial recognition and even technology that recognizes the specifics of individual motor skills. It aims to assess the creditworthiness, reliability, and performance of individual citizens by ranking and evaluating their "moral integrity", which manifests itself in various behaviours, from frequency of visits to parents to trustworthiness, work habits, and adherence to traffic rules. Moreover, the consequences of such evaluations are revealed in the concrete punishments and rewards of the observed individual.

Digital technologies are certainly about much more than a set of algorithms. Their attachment to ideologies is inherent, as the production and development of these technologies is based on the assumption that a selection of digital systems, shaped by a small technical elite, can over time take on a life of their own, to the point where they not only complement but displace humans. This assumed ability to replace human judgement with systems created and implemented by a small technical or theoretical elite distanced from interactions with the real world is what links these contemporary ideologies to the surviving ideological relics of so-called "real socialism" and its centrally planned production. "It is thus not all that surprising that the Chinese Communist Party would find AI to be a welcome technological formulation of its own ideology" (Lanier and Weyl 2020). ${ }^{7}$

On the other hand, however, the development of the COVID-19 pandemic in East Asia has clearly shown us that digital technologies and large databases can

7 However, it is somewhat more surprising that, at first glance, leading Western technology companies and governments have been quick to adopt a number of similar ideologies that relate to artificial intelligence as such. One of the reasons for the rapid spread of such technologies is perhaps the loss of faith in the institutions of liberal democracy, which — despite everything - are supposed to be based on the values of human freedom and dignity, and not just on the worth of capital and profit. It is therefore no coincidence that today the richest companies, individuals and regions are precisely those closest to the most powerful computers for data collection. In this context, artificial intelligence may point to the death of the pluralistic visions of traditional liberal democratic marketing (Lanier and Weyl 2020). It is therefore increasingly clear that we need to rethink and ask ourselves once again what role technology plays—and should play-in people's lives. 
also be used autonomously and in a liberating manner, and not only as tools of all-encompassing centralist control, as China is striving for with its system of social credits.

A very telling example of such a change in mentality and the function of technology can be found in Taiwan. Almost half of the population on this island voluntarily joined the state's platform for organizing and sharing data even before the pandemic began, allowing citizens to autonomously organize the use of data and demand services in exchange for it, to participate thoughtfully in public decision-making, and to vote in innovative ways on numerous state issues.

Driven neither by pseudo-capitalism based on barter nor by state planning, Taiwan's citizens have built a culture of agency over their technologies through civic participation and collective organization, something we are starting to see emerge in Europe and the US through movements like data cooperatives. (Lanier and Weyl 2020)

In Taiwan, numerous data (or digital) cooperatives have already emerged in the early 21 st century. The most interesting thing here is that the tools derived from such approaches have played a key role in Taiwanese successes in controlling COVID-19. Digital cooperatives are built on grassroots democratic principles. In such associations, digital data belong to the cooperative members, who manage and use it for purposes that do not involve community control of individuals, nor do they have the exclusive goal of profit-making, but rather are guided by the aim of achieving transparent equity for all members.

Taiwan even has a minister without a portfolio for Digital Affairs, Minister Tang Feng (Audrey Tang), ${ }^{8}$ who contributed in important ways to Taiwan's unforeseen success in limiting and stopping the spread of the epidemic by democratically disseminating digital technologies for disease control and tracking accessible medical devices, and who emphasizes the value of digitization in the context of the widest possible consensus among the entire population. The measures she proposed were based solely on recommendations, as no one was forced to adopt the digital applications used in the process. Nevertheless (or precisely because of this), they were voluntarily used by a large majority of the Taiwanese population. This is what she sees as enabling Taiwan's successes in fighting the epidemic, especially during the first and the second waves. Tang stresses that forced action is not an effective means of combating the epidemic: "Any top-down coercion, whether from capitalists or the state, is equally bad" (Audrey Tang in Kim 2020,12).

8 Tang is a transgender person who was known as Tang Zonghan, or Atrijus Tang before her gender transition. 
In the case of Taiwan, one of the reasons for the acceptance of digital technologies in the fight against the epidemic is the confidence of the majority of the population in the state and their fellow citizens. In China, on the other hand, with the wide acceptance and positive evaluation of the social credit system based on digital control, we see an idea diametrically opposed to that of mutual trust, or privacy protection. Moreover, the Chinese online social network WeChat is more or less ubiquitous, as it has increasingly become an indispensable part of everyday life and communication, a way to access important information and use public infrastructures, from public transport to libraries.

Despite all the major local differences between autocratic and democratic societies in East Asia, which can be observed in the use of digital technology, it is nevertheless obvious that the general attitude towards digital objects in the whole Sinic cultural and linguistic area differs considerably from that in the West. Among other things, this is related to different traditional notions of intimacy and privacy, ${ }^{9}$ but it is also rooted in traditional attitudes toward or perceptions of technology in general and digital technology in particular. Let us therefore consider the actual relationship between humans and this particular kind of technology from the perspective of Chinese intellectual history, for these specific attitudes or perceptions are built on a common foundation of a cosmotechnological view that is also representative the wider Sinic space.

\section{Cosmotechnology and Technodiversity}

Cosmotechnology is a term that refers to the various different relationships between humans and technology as developed in different cultures and their corresponding symbolic, economic, and linguistic worlds. In other words, it is a part of the cosmologies associated with the specific attitudes of individuals and communities toward various specific techniques that are vital to their survival, and toward technology as a coherent, rationally ordered system of those techniques. In this sense, cosmotechnology is a system based on the combination of the cosmic and moral, aesthetic or axiological order in the acts of practicing and passing on techniques. In the history of humankind, many different systems of understanding or explaining the cosmos have evolved, as have many different techniques. Therefore, there cannot be only one cosmotechnology (i.e., the European one), for there exist as many individual cosmotechnologies as there are symbolic orders of perceiving

9 I have dealt with these differences regarding the perception, understanding and role of privacy and intimacy in Chinese and European intellectual history in great detail in my recent book on COVID-19 in East Asia (see Rošker 2021, 152-56). 
and understanding the cosmos. This culturally conditioned miscellany of different techniques and cosmotechnologies is called technodiversity. ${ }^{10}$ It consists of orders that are culturally and linguistically conditioned, while the process of applying techniques and designing their products is, as such, universal.

The question of the relationship between universality and the (culturally conditioned) particularity of techniques has long agitated the minds of innumerable philosophers, anthropologists, psychologists, linguists and scholars of social sciences. Here, it is worth mentioning the French archaeologist and anthropologist André Leroi-Gourhan, who established the notion of technical tendencies arising from the relationship between the two. In his book Environment and Techniques (Milieu et techniques 1945), he tried to present this relationship within the framework of the general theory of dynamic interactions, in which human communities behave as complete organisms living in the environment defined by external (geography, climate) and internal (culture, tradition) factors. He named the natural and social environment as the external and internal milieus (Leroi-Gourhan 1945, 333). In this framework, the concept of technical tendencies represented a movement or tendency that forms within the inner milieu and becomes the primary factor influencing the functioning of the community in its natural environment.

Contemporary Chinese theorists have also devoted much attention to determining the relationship between the universal and culturally conditioned factors. ${ }^{11}$ One of the most important representatives of philosophical anthropology is $\mathrm{Li} \mathrm{Ze-}$ hou, who considered techniques, in the sense of the making and systematic application of tools (as well as the intergenerational transmission of the corresponding

10 Technodiversity emphasizes the need for the simultaneous existence of different kinds of relationship between human beings and technology, which manifest themselves in different paradigms of cosmotechnology. Yuk Hui, a scholar of informatics and philosophy from Hong Kong, believes that understanding different culturally conditioned forms of cosmotechnology (or, as he himself calls them, cosmotechnics) is important because it can prevent a universalistic equalization of ideas (or ideologies) about the role and manner of interaction between humans and technology. In other words: technodiversity is a term which is based upon different patterns of cosmotechnology, i.e. the relationship between humans and technology. In this context, it emphasizes cultural diversity. It is an understanding based on technological diversity that allows for multi-layered and pluralistic starting points for the study of such relationships. On such foundations we have produced throughout history a number of different forms of knowledge, linked to the world and the Earth in different ways and through diverse, specific, multi-faceted relationships that cannot be measured solely by the criteria of the linear progress of modern science and technology. Only an understanding of the existence of such heterogeneity (as opposed to the isolated contributions of individual "nations" and "cultures") will allow us to resolve the tensions between increasingly isolated social groups.

11 Of course, this is by no means a specific interest of Chinese scholars. Many Western philosophers, anthropologists, and even political scientists have also elaborated on this issue, see e.g. Rockmore $(2019,56)$. 
techniques), as the basis of becoming human, and thus as the decisive characteristic that distinguishes humans from (other) animals.

Many scholars believe that tools are extensions of human limbs or organs, and thus Li Zehou speaks of human beings as beings for whom tools or techniques are a "universal necessity", since humans represent "supra-biological beings" who could not survive without all these extensions of their bodies Li Zehou 2016, 28). Further similarities between the philosophical anthropology of Leroi-Gourhan and Li Zehou can also be found in the fact that both see technology as a form of externalization of human memory (Leroi-Gourhan 1993, 219 ff.; Li and Cauvel 2006, 3).

The culturally defined dimensions of technology are thus at the forefront of the conceptualization of different cosmotechnologies as different externalizations of memory. This is the search for a new frame of reference for technology, a new framing of its interpretations that will transcend both the ancient Greek concept of techné (including its connotation of creation or poiesis) and Heidegger's concept of the Gestell, which for him marked the essence of modern technology (Heidegger 2000, 21).

But what are the defining or characteristic features of the specific Chinese cosmotechnology? How does it contribute to the global technodiversity? Within the framework of such questions, Yuk Hui has set himself the task of systematically examining the ancient concepts of dao 道 (the Way, method, original principle) and $q i$ 器 (vessel, accessory, tool, device). This pair of terms appears for the first time in the history of written Chinese together in the ancient Book of Changes (Zhou Yi), where it is described as follows: "What is above the forms we call method (dao), what is below them we call tool (qi)."12

In the quest for Chinese cosmotechnology, then, Hui's starting point is certainly correct and sensible, but his interpretation of this pair of terms and their meaning is problematic, as he sees in them a kind of Cartesian dualism (Hui 2018, 2), which is certainly not true. Indeed, these two opposite poles have the typical form of a binary category, which does not operate according to the principle of contradiction but rather to that of mutual complementarity. ${ }^{13}$ Even though the two models of dialectical oppositions have already been explained in many sinological writings, I would like to reiterate here the theoretical foundations of this distinction, since in this context it is situated in the concrete example of understanding the relationship between the basic principles of human existence and technology. In this context, it is even more important for understanding the given criticism of Hui's theory.

12 形而上者谓之道, 形而下者谓之器.

13 For a detailed explanation of the differences between Cartesian dualism and the model of binary categories, see Rošker (2021, 48ff); and Tian (2019). 
Both cases represent a form or theoretical model of binarity in the sense of a relation between two opposite poles. In Cartesian dualism, the two opposing poles stand in a mutually exclusive relationship, i.e. they are not only opposed to each other, but are in mutual contradiction, which is best seen in the construction of Hegel's dialectic, within which they are usually interpreted as thesis and antithesis. Both dualism and the dialectic derived from it are only possible on the basis of a static and unchanging understanding of being, as formed within the paradigm of Parmenides, which at the same time allows for the development of the basic principles of formal logic in terms of the laws of identity, non-contradiction and excluded middle. In the model of complementarity-based dialectics, the opposite poles are in mutual opposition, existentially defined by co-dependency and at the same time enabling their mutual completion. In this model, the opposing poles constitute two sides of the same coin; their difference and mutual delimitation is the basic condition for the existence of the whole of which they are essential parts. It is also important to note at this point that this model does not produce a qualitatively separate synthesis of the two opposing poles that could exist as an independent new entity, since synthesis is constantly present precisely in the interaction between the two. Since this is a typical model based on process philosophy, formal logic has no valid basis within its framework.

This has far-reaching consequences for understanding the specifically Chinese relationship between technology and nature, and thus for the Chinese system of cosmotechnology and science itself. The comparison between the terms dao and $q i$ and the ancient Greek terms techné and areté is particularly problematic. While dao is said to be the superior and primary factor compared to $q i$, the ancient Greek worldview is said to be more instrumental and (at least from Aristotle onwards) to place more emphasis on the importance of the means to achieve goals (Hui 2016b, 89). The latter claim, referring to ancient Greek philosophy, is undoubtedly correct, and in what it describes we can observe the essence of what later, in the last two centuries of the previous millennium, shows itself to be the basis for Western-type modernization, namely instrumental reason. Hannah Arendt therefore also sees the origins of this in the tendencies that determined the development of the ancient Greek relationship between action and production or manufacture, within which the first-already in Plato's theories-was gradually but consistently transformed into the second:

How persistent and successful the transformation of action into a mode of making has been is easily attested by the whole terminology of political theory and political thought, which indeed makes it almost impossible to discuss these matters without using the category of means and 
ends and thinking in terms of instrumentality ... We are perhaps the first generation which has become fully aware of the murderous consequences inherent in a line of thought that forces one to admit that all means, provided that they are efficient, are permissible and justified to pursue something defined as an end. (Arendt 1998,229)

But if we now build on this and look more closely at the part of Hui's comparison that relates to the ancient Chinese understanding of technology and its use, his interpretation quickly proves problematic. The core problem is the aforementioned fact that Hui does not understand the difference between Cartesian dualism and binary categories. If we follow the assumption that the relationship between method (dao) and device or tool $(q i)$ is not a Cartesian dualism, but-like most other conceptual pairs within the Chinese tradition of ideas-belongs to the model of binary categories, then we will have a hard time arguing that within the complementary correlativity of their mutual relationship one of these opposite poles is indeed primary, even though methods (dao) as such can be used in other places and in completely different activities that are not tied to the device (qi). In this broader context, where it is an overarching category, method (dao) is certainly more fundamental. It is also true that a device $(q i)$ as a tool cannot function without the method (dao), since its use is necessarily tied to it. But in the concrete model of their mutual relationship, which is also the basis of their joint activity, the method cannot exist without the device either. We must distinguish here, then, between method and device as independent categories, on the one hand, and method and device as equal parts of the same complementary model, in which they are correlative and interdependent, on the other. In the former case they can exist without each other, but in the latter each of them depends on the other, opposite pole, and neither of them is primary or a cause of the other.

\section{Traditional Differences and Modern Universalism}

In interpreting this pair of terms, then, we must continue to know that they are both categories, not concepts. An important contemporary Chinese philosopher, Zhang Dainan (1909-2004), has pointed out that we cannot understand Chinese intellectual history without understanding these kinds of distinctions. Zhang sees concepts as a form of naming concrete things and phenomena. These designations may include other, more general entities as well as their partial or narrower special properties, but they always refer to the concrete meaning of the words. Categories, on the other hand, are only the formal, arbitrary tool for analysing reality. On this basis it is easier to understand that the term dao in the context of the 
proto-philosophical classic Book of Changes has no moral connotations as attributed to it by Yuk Hui. Such a meaning was ascribed to the word dao only much later, through Confucian commentaries on this work, and thus also exclusively in the context of the Confucian view of the cosmos. Of course, we must take into account here that such an understanding, within which the universe is saturated with moral principles, had due to the dominant position of Confucianism, already acquired a paradigmatic status in the early Middle Ages. This moral component is particularly noticeable in the compound word rendao 人道, which refers to the "Way of Humankind" and describes human ethical maxims. ${ }^{14}$ In the Book of Changes itself, which is much older, dao is seen only in its most basic meaning of the Way, that is, the methods, principles and modes of action.

The same is true of the descriptions of the relation between the words dao and qi, that is, of those parts of the text which refer exclusively to techniques in the sense of the relation between physical tools and immaterial methods of their use. On the other hand, however, Hui equates the word dao, which in the above quotation refers to that which is "above the forms", with noumenon in the Kantian sense (Hui 2017b 8), but in the same breath (only slightly earlier) criticizes the translation of the phrase xing'er shang xue (literally: above the forms) with the term metaphysics ${ }^{15}$ (ibid.). Thus, such a comparison seems premature, especially if we bear in

14 The opposite pole to the word rendao 人道 is the term tiandao 天道 (literally, the dao of Heaven or nature), a cosmological term characteristic of Daoist interpretations of the category of dao. In later Confucian texts, e.g., The Analects, the word dao is used quite frequently in the sense of "the right" way (or method), and this "rightness" has very clear moral connotations. Whereas the word qi in the sense of "tool" or "device" is often used in these sources in its adjectival function, meaning to master certain techniques or to possess certain skills needed to perform certain kinds of tasks. A good example of such a development of meaning can be found in the $Z i$ Lu chapter of the above-mentioned work, which states, "Exemplary persons are easy to serve but difficult to please. If we want to please them in a way that is not morally appropriate, they will not be pleased. Exemplary persons employ people according to their skills. (君子易事而難說也: 說之不以道, 不說也; 及其使人也, 器之.)”( Lunyu s.d. Zi Lu, 25)

15 Here Yuk Hui explicitly demands that such an equation (of the expression "above the forms", i.e. "xing'er shang xue" and the term "metaphysics") be abolished. Although I fully agree that the translation is inadequate, I cannot defend his proposal. First, the term metaphysics is often (mistakenly) interpreted in the West as the name of a discipline that, according to its name, is supposed to be concerned with the transcendent sphere that goes beyond the sphere of sensually perceptible (form-giving) reality. It is known that Aristotle's Metaphysics, whose title is the first instance of the use of this term and from which the term derives its paradigmatic meaning, takes its name only from the editorial note written in the 1st century AD. This is because the text's first-century compiler (most likely Andronicus of Rhodes) added the title "Metaphysics" to indicate that the book was a collection of essays that followed Aristotle's natural philosophy (i.e., "physics") (see, e.g., Cohen in Reeve 2020,1). The Chinese translation has exactly the same etymological meaning as the ancient Greek original. Of course, this does not mean that it (or the modern meaning of the term metaphysics) overlaps with it in all related semantic connotations. Nevertheless, xing'er shang xue is a term too well established in pre-modern, modern, and contemporary Chinese philosophy to simply "correct" it arbitrarily and deliberately, to interchange it with any other, as this would lead to additional confusion within comparative and transcultural philosophy. 
mind the dangers of misinterpretation that we face if we do not take into account the different frames of reference, which define many cultural differences in different philosophies (see for instance Heubel 2019; Tian 2019). We must therefore be careful in such places; from the mere fact that in a certain passage in the Book of Changes dao is referred to as something above the forms, while $q i$ is referred to as something below the forms, we can by no means infer that the former refers to the noumenon and the latter to the concrete objects or phenomena.

This, of course, does not detract from the value of Hui's original assumption that the Book of Changes, as a central work of the earliest Chinese philosophy of nature and life, implicitly asserts through such an explanation of the specific relationship of dao and $q i$ that tools must necessarily follow the method of application in their handling (Hui in Dunker 2020,14). It is also important to point out here that the method itself must also conform to the nature or internal composition of the device or the tool; in the process philosophy of this work, the opposite poles of the complementary binary categories always follow and complete one another. This represents a kind of relationship between technology and human beings, in which the application of technique (qi) is in harmony with method (dao). Dao in this context is method in the broadest sense, for it can also be seen as a general philosophical guideline that shows us the way out of chaos, the complex jungle of wild and untamed nature.

In his book The Question Concerning Technology in China (2016a), Hui tries to figure out the ways in which Chinese philosophy can help us think through the supposed contradiction between tradition and modern technology. His rationale is to find a way out of the universalistic tendencies of technological singularity, which is the product of Western-style modernization, and globalization, which is its result. According to Hui, this kind of technological singularity would lead to apocalypse (Hui in Dunker 2020,14). He wants to overcome this dangerous tendency by introducing the so-called "techno-diversity" or technological multiplicity, which is based on different epistemological approaches and paradigms of human attitudes towards technology and nature. This is represented in the triad of cosmic order, humans and technology, which is manifested in the concept of cosmotechnology. What Hui uncovered in his further explication of the traditional Chinese relationship between method and device ${ }^{16}$ is, among other things, that the cosmos as such was seen in prevailing (i.e., especially Confucian) Chinese philosophy as

16 In his book, Hui charts the evolution of the relationship between dao (method) and qi (device) throughout Chinese intellectual history, focusing on three phases that he sees as key to the development of this relationship and the changes therein: 1) the phase of pre-Qin philosophy and the philosophy of Han dynasty, 2) the phase of Neo-Confucian philosophy, and 3) the phase of modern philosophy that emerged based on the adoption of Western technology and thought. 
a sphere saturated with values. This axiological component, expressed in Chinese moral philosophy and ethics as well as in traditional Chinese aesthetics, has always prevented the reduction of technology to its applicability in the sense of instrumentalization. With modernity, this view of the triad of humans, technology and cosmos changed fundamentally, conditioned by the (then necessary) adoption of superior Western technology and the ideas on the basis of which it had been developed.

However, taking into account the specifics of the crisis that China faced at the time of the adoption of Western technology, another fact is important here, and that is that the adoption occurred precisely at the time when there was a crucial transition within the development of technology itself. Modern technology, with new techniques such as various forms of radiation, electrical energy, and data transmission through immaterial waves, surpassed the function of extending human organs (and limbs) and externalizing human memory that it had before. ${ }^{17}$ It was precisely the latter, that is, the externalization of memory, that had the function of preserving and transmitting technical knowledge in the earliest and simplest forms of technology, for which it was characteristic that they created and thus displayed objects that had not previously existed in nature. For humans, technology has always been closely connected not only with their being human and the discovery and development of themselves, but also with the process of discovery and development of the world. As mentioned earlier, the first form of discovery of reality in the Western intellectual tradition is tied to the usefulness of the objects in it (Hui 2016a, 89). In capitalist production and reproduction, this utilitarianism was also applied to nature, which thus became alienated from itself. All its axiological components, including ethics and aesthetics, became subordinated to the demands of application. In this way, modern developments have distanced technology itself from the simple relationship between the end and the means to achieve it. Thus, instead of seeing technology as a kind of extension of basic human tools, Heidegger $(1979,16)$ warns that modern technology also brings with it its own laws. For him, the problem with modern technology lies not only in the fact that, unlike traditional tools, it uses sources of energy that are external to humans and their labour, but rather in its dominant character. Even though technology does not take place outside of human agency, with modernization technical processes have to some extent become independent,

17 For an extremely rigorous analysis and interpretation of these two functions and their role in the constitution of humanness, see Li Zehou (2016). In the same work, the cultural features of technological development in China are analyzed in detail, with $\mathrm{Li}$ focusing on the group condensation of memory through the processes of specific types of rituality that accelerated and fortified mental sedimentations through which technology was passed from older to younger generations. 
reducing humans to producers who essentially only ensure that technology exists and thrives. Within this new framework, the human is no longer the basic framework, i.e. the Gestell (Heidegger 2000,15) that "launches" the existence and development of technology-instead, this function is taken over by technology itself. In the processes of modernization, human beings, who on the one hand ruled over nature and became its supreme masters, lost their previous function and their Selves, and became more and more alienated from the world and its truth. According to Heidegger, this should not lead us to hatred of technology and technological development (cf. Heidegger 1969, 12'03"), but rather to a desire to understand and reflect on both (Heidegger 2000,15) and to arrive at the transformed (and at the same time completely new) discovery of the demand for human freedom hidden in the very essence of technology. This is indeed the very "enframing" (Gestell) of the modern world (ibid., 26). Heidegger thus created a theoretically innovative and lucid foundation for the modern philosophy of technology and the ontological basis of the paradigmatically altered use of energy sources. However, this philosophy has faced new challenges in recent decades, as we are now dealing with immaterial, digitalized sources that require the establishment of new ontological theories.

\section{Ontology of Digital Objects and Structural Onto-Epistemology}

The World Wide Web as a network of data has presented us with new challenges related not only to the discovery, isolation and exploitation of techniques for storing and using energy, but also to the existence of digital objects. These are dynamic, relational units of data, embedded in networks, which Luciano Floridi $(2014,97)$ calls infospheres. The concept of the digital object can help us understand modern automated systems of online interactions. This is because through the lens of digital objects we can redefine such systems

in a way that passes through the concepts of preindividual milieu, individuation, world, being-in-the-world, Zuhandenheit and its associated milieu-which may in addition provide new resources with which to interpret the notions of Gestell and Ereignis, through which Heidegger explored the cybernetic age. (Stiegler 2016, viii)

The Hong Kong philosopher of technology Yuk Hui defines these as objects "that take shape on a screen or hide in the backend of a computer program and consist of data and metadata governed by structures or schemas" (Hui 2016b 1). These give semantic and functional meaning to the metadata (i.e. data about data): "In 
computer science, these schemas are also called ontologies - a word that immediately evokes associations with philosophy" (ibid.).

In this way, digital objects provide a good basis for a new metaphysics and ontology_or at least for an updating and extension of it (Stiegler 2016, ix). Within such an understanding, a digital object then constitutes discursive relations on the basis of which it is itself also interwoven; with such interconnectedness of itself, it establishes its own existential relations (ibid., xi). A digital object belongs to computers and is therefore by its very nature technical, but it cannot be limited to technology alone. Hui's understanding of digital objects even goes beyond the questions about such objects as they are treated by application-oriented computer technology, which usually reduces them to a set of representational structures. In his reflections, Yuk Hui does not stop at engineering pragmatic questions of digitality as a phenomenon, but tries to understand its existential status (Hui 2016b 3). In doing so, he starts from assumptions similar to those expressed in Quine's slogan: "To be is to be the value of a variable" (ibid. 273, fn. 73).

In the digital age, then, there is a burning necessity to question the being and modes of existence of digital objects. Since they consist of relations and connections between data schemata, these objects are only concretized as such through the materialization of these relations: "The genesis of digital objects is the process of concretization and materialization, first of forms, second of explicit relations and connections between objects" (ibid., 72). This gives a new form or a new way of existing in the world, in which we are again confronted with new questions: "We may want to ask, to what extent can we value this philosophical trajectory of relations as we have outlined it?" (ibid., 142).

Here, then, we are concerned with the transformation of quantitative structures of data into qualitative communicative-semantic or even axiological values. In this way it should be possible to overcome man's alienation from technology, which arises from not understanding these values:

The most powerful cause of alienation in the world of today is based on misunderstanding of the machine. The alienation in question is not caused by the machine but by a failure to come to an understanding of the nature and essence of the machine, by the absence of the machine from the world of meanings, and by its omission from the table of values and concepts that are an integral part of culture. (Simodon 1980,2)

Contemporary technological systems, driven by digital technology, have a tendency to lead to a homogeneous relationship between humans and technology. However, for this very reason, and because of the need for technodiversity, it is 
necessary and important for different cultures to reflect on their own histories and ontologies within the framework of their own specific languages and symbolic orders, because only in this way will they find ways to accept and adopt digital technologies without disappearing and merging into a homogeneous, synchronized unit of a "global" and "generic" system of acquiring knowledge and understanding about reality. Only in this way will humanity be able to preserve, even in the global age of digital technologies, the possibility of different attitudes to the world and different ways of seeing and understanding new realities. And this, as we know, is the basis of human freedom and autonomy.

In this respect, Chinese philosophy may also open up some new possibilities. Here we may recall the modern Chinese structuralist Zhang Dongsun, who-partly under the influence of Chan Buddhism and its specific conception of reality based on the illusory character of the phenomenal world — created a system of structural-relational onto-epistemology in which there is no substance, since the world consists exclusively of relations. Such a relational nature of knowledge acquisition is at the same time the basic paradigm of most Chinese epistemologies, which are based on the assumption of structural compatibility between the external world and human consciousness (see Jiang 2002, 65).

Zhang Dongsun is undoubtedly one of the most important Chinese philosophers of the 20th century. Although he was-due to his criticism of the Sinicization of Marxist ideologies and his role as a political dissident-almost completely and unjustly forgotten for a while in the last decades of the century, in recent years there has been a growing interest in his work among Chinese theorists. Zhang's philosophy is particularly significant in the field of theory of knowledge, which began with a pluralistic epistemology and culminated in a cultural one (ibid., 57).

As a starting point, Zhang established an innovative system of a pan-structuralist cosmology, in which we can also see the influence of Chan Buddhism. This system formed the basis of his specific worldview. Zhang Dongsun's cultural epistemology, based on a pluralist epistemology, is derived from the assumption of cultural conditioning or the culturally conditioned nature of knowledge. ${ }^{18}$ Another important assumption of his epistemology is the neorealist position, according to which the external world exists independently of our consciousness, and there is no precise correlation between the phenomena of the external world and our perception of them. This Kantian legacy implies, of course, that we can never perceive

18 This aspect of his philosophy is still very relevant and valuable today, especially in the field of methodology of transcultural research. His studies in cultural philosophy are based on detailed comparative analyses of Chinese and European thought. Particularly important here is his research on the influence of the structure of language on different philosophical systems and on the connections between cultural differences and the formal logical systems of different traditions. 
external objects as they actually are. According to Zhang, the external cause for our sensation is not a substance, but the order or structure of the external world. What is transmitted to us through our sensory impressions is a modification of this external order (ibid., 59) In interpreting the basic structure of reality, he also referred to scientific discoveries regarding atoms and their most elementary structures, which transcend the categorical boundary between particles of matter and non-substantial electromagnetic waves. Here, his critique of substance was quite radical, and he denied the real existence not only of the smallest particles of matter, but also of quanta, electrons and even electromagnetic waves.

The denial of substance also refers to the sphere of ideas. As in Chan Buddhism, all that we perceive is not only empty in the sense of substantial absence, but also illusory. Therefore, Zhang's cosmology is neither materialistic, nor idealistic: "Pluralistic epistemology ... rejects 'substance' and is of the opinion that the dualistic theories of idealism and materialism are completely wrong." ${ }^{19}$ (Zhang 1995, 214)

One reason for our inability to recognize the essence of external things "as such" is thus to be found in the very nature of their existence; for Zhang, who did not acknowledge the existence of substance, reality was a process of constant change that manifests itself in the inter-relations of particular entities. In contrast to Kant, who did not abandon metaphysics, even though he gave priority epistemology, which radically altered its role, Zhang's cosmology is not metaphysical. In his system the impact of Chan Buddhism is much stronger (Jiang 2002, 63). Because he rejected the existence of substance, he emphasized that the objects perceived by us can not possess any "ontological status" (Zhang 1995, 215). All beings exist in a process of constant change that manifests itself in a never-ending modification of structural connections, and the growth and decline of the qualities of the "essence" of particular entities. According to Zhang, our consciousness can only recognize certain aspects of these manifest changes. However, this refers not only to the level of our perception and comprehension; according to Zhang, the structured order of relations is all that really exists in the cosmos. Zhang argued that all these structures are empty, for they possess neither substance, nor its qualities. The level of material being ( $w u$ 物) is thus a merely physical phenomenality which cannot be equated with material substance, but, at the most, with structural relations and the physical laws which determine its existence (Jiang 2002, 64).

Hence, Zhang's cosmos does not imply any substance or essence; it exists solely as a relational process of structural order. However, even this order is not totally natural and objective, but also depends upon our cognitive activities:

19 “認識的多元論...勢必根本上否認 ‘本質’ (substance), 以為本體論上的唯心論唯物論兩元論全 是不對的. 
However, these structural forms as such do not entirely belong to external things as such ... From the viewpoint of essence, there are no external things. But with respect to structure and form, most of the forms result from the process of comprehension. In other words, they belong to the domain of subjectivity. ${ }^{20}$ (Zhang 1995, 171)

All external structures are manifested in our mind, that (re)-establishes them in the process of forming structural patterns of thought and comprehension. However, Zhang's theory is not solipsistic, since the external reality for him is not an exclusive product of our recognition: "At least some of these structural forms are not just a product of the laws of our recognition"11 (ibid.). The relation between the external world and our subjectivity is interactive and correlative:

Our cosmos does not possess any essence; it is only a structure. Its constitution is not entirely natural, but inseparably connected with the function of our recognition. Without recognition we could get a glimpse of the original image of this structure. But it still cannot completely seize its essence. Therefore, we can still claim that the cosmos is a structure. ${ }^{22}$ (ibid., 218)

In this view people, or rather our minds (but also our biological bodies, as these are inseparably tied together), are fundamentally structured in the same way as the cosmos. However, this does not only imply homogeneity, which would allow inference from objects of the external sphere to objects of the internal sphere, as Bertrand Russell assumes in his structural epistemology, but also a direct flow of data, which at the same time represents states of relational structures moving from one sphere to another.

In his pan-structural epistemology, based on the plurality of the cognitive process (Rošker 2008, 264-87), Zhang thoroughly shows how our minds are supposed to transform such informational signals originating from what he calls the "external order" into the axiological and aesthetic values of our individual interior space through a series of a priori forms. Since Zhang here, as mentioned earlier, takes as his starting point not only the Chan Buddhist onto-epistemology but also a classical Chinese understanding of the cognitive process, it is important to see

20 但這些構造方式固然不是完全屬於外物本身的...以實質而言, 本來就沒有外物. 以構造與方 式而言, 大部分的方式仍是屬於認識作用本身的, 換言之, 即屬於主觀的.

21 這些構造方式... 其中至少有若干是不由于我們的認識立 法所造.

22 我們這個宇宙並無本質, 只是一套架構. 這個架構的構成不是完全自然的, 而必須有我們的 認識作用參加其中. 因為我們不能拔開認識以窺這個架構的本來面目. 然而亦決不十分大虧 其本質. 所以仍可以說宇宙是個架構. 
that what is also at stake here is the compatibility of two relational structures, the external and internal, both of which can be seen as carriers of meaning and axiological values. The basis of the prevailing Confucian ethics is the moral core of the order of the universe, or what Zhang calls "external order". The axiological foundations are, within this frame, already contained in the signals themselves, which the forms of our minds only need to decode correctly.

\section{Conclusion}

Within this view, digital objects, as insubstantial data structures of relations within their own infospheres, should also exist as systems that are directly and organically compatible with our minds, not only in the sense of transmitting information, but also in the sense of meaning and value. Similar to relational ethics and Chan Buddhist onto-epistemology, which we introduced in the previous section using the example of Zhang Dongsun's system, Chinese cosmotechnology is also based on relationships, on a relational network of innumerable connections between humans and technology, arising from a binary relationship between $d a o$ and $q i$, i.e. between the immaterial method and the physical device or tool.

One of the reasons, then, that people in Sinic societies are more inclined to the digitalization of life and less suspicious of digital objects lies precisely in the relational nature of the latter. This is not only because relationships are central to Sinic ethics, as they also form a foundation of Sinic onto-epistemologies, that were briefly discussed in the previous section. One could argue that they provide the basic modus vivendi that defines the fundamental symbolic order of Sinic societies. This is, of course, an extremely subtle factor, operating on a subconscious level. On the other hand, such a relational foundation of life, which may link the ontologies of digital objects to the mode of existence of the pure and unalienated humanity, can by no means be the only reason for the general Sinic preference for information technologies. Rather, this kind of Sinic inclination toward digital life forms is in all likelihood also the result of a whole range of other factors. As already mentioned, one of them is surely connected with the specific Sinic understanding and perception of the concepts of privacy and intimacy (see Rošker 2021, 152-56). ${ }^{23}$

One of these probably has much to do with the fact that the people of the Sinic area, in their specific processes of modernization, may not have fully internalized

23 This reference is to a book written and published in my native language. However, the chapter on privacy and intimacy will also form part of my new book on COVID-19, which will be published by Bloomsbury in 2022 . 
the culturally conditioned forms of Enlightenment values on which modern science is based. This is not to say, of course, that there is no positive appreciation of the ideas of freedom, autonomy, and rationality in Sinic societies. I merely wish to point out that such concepts arose differently in the Sinic (especially Confucian) intellectual traditions, and that their ideational foundations are therefore different from the paradigms on the basis of which they arose in European history, and especially in the Age of Enlightenment.

The digitalization of our lives demands - and will probably demand in the future - many sacrifices from us, because in the course of its development we have to give up many values and ideals of modernity, which were created on the basis of European Enlightenment and were given to the majority of people born and raised in Western societies through their earliest socialization.

As digitalization is likely to take a much more important role in our lives in the future, it would certainly be appropriate for people in Europe and other regions of the so-called Western world to also engage with it in a different way and try to develop such conceptualizations of autonomy, freedom and democracy that are compatible with it. With this goal in mind, it is certainly a good idea to look beyond the narrow limits of Enlightenment conceptualizations of the subject and consider alternative forms of the human self and personhood, such as the ones, for instance, that can be found in the Confucian relational ethics. Such ethics can help us to establish a relational view of reality, which can also help us develop a closer and less fearful connection to the relational nature of digital objects, and hence, the digital world in general.

Indeed, digital technology can provide us with a powerful tool for combating pandemics, ecological disasters, global poverty and so on. We must therefore learn to use it autonomously and responsibly, and actively create the political and economic conditions for such positive application. The most important prerequisite for such use of digital technologies, however, is transcultural mutual learning-but first we must learn to listen to each other.

\section{Acknowledgement}

The research for this paper was supported by the Slovenian Research Agency (ARRS) in the framework of the research core funding Asian Languages and Cultures (P6-0243) and in the scope of the research project N6-0161 (Complementary scheme) Humanism in Intercultural Perspective: Europe and China. 


\section{References}

Arendt, Hannah. 1998. The Human Condition. Chicago: University of Chicago Press.

Bauer, Wolfgang. 2000. Geschichte der chinesichen Philosophie. München: C.H. Beck. BBC News. 2020. "Covid: Merkel Warns of 'Long, Hard Winter' as Lockdowns Return.” Accessed November 7, 2020. https://www.bbc.com/news/ world-europe-54728893.

Buras, Piotr. 2020. "First Hungary, now Poland. It's time for Europeans to Speak Out Against COVID-19 Power Grabs." Euronews, April 15, 2020. Accessed November 7, 2020. https://www.euronews.com/2020/04/15/first-hungarynow-poland-time-for-europeans-to-speak-out-against-covid-19-powergrabs-view.

Cohen, S. Marc in C. D. C. Reeve. 2020. “Aristotle's Metaphysics.” In The Stanford Encyclopedia of Philosophy (Winter 2020 Edition), edited by Edward N. Zalta. Accessed December 15, 2020. https://plato.stanford.edu/archives/win2020/ entries/aristotle--metaphysics/.

Dunker, Anders. 2020. “On Technodiversity: A Conversation with Yuk Hui." Los Angeles Review of Books, June 9,2020:1-23. Accessed October 20,2020.https:// lareviewofbooks.org/article/on-technodiversity-a-conversation-with-yuk-hui/. Floridi, Luciano. 2014. "The Rise of MASs." In Protection of Information and the Right to Privacy - A New Equilibrium?, edited by Luciano Floridi, 95-122. New York, Dordrecht, London: Springer.

Heidegger, Martin. 1969. "Interview mit Richard Wisser (1969)." Accessed December 6, 2020. https://www.youtube.com/watch?v=k7S0xER_cg0.

1979. "The Question Concerning Technology." In The Question Concerning Technology and Other Essays, translated by William Lovit, 3-35. New York/London: Garland Publishing, Inc. Accessed March 19, 2021. https:// monoskop.org/images/4/44/Heidegger_Martin_The_Question_Concerning_Technology_and_Other_Essays.pdf.

—. 2000. "Die Frage nach der Technik." In Gesamtausgabe I, 7: 5-36. Frankfurt/ Main: Vittorio Klostermann.

Heubel, Fabian. 2019. "Beyond Murderous Dialectics: On the Heritage of Paradoxical Thinking in Maoism.” Asian Studies 7 (1): 37-54. https://doi. org/10.4312/as.2019.7.1.37-54.

Huang Yasheng, Sun Meicen, and Sui Yuze. 2020. "How Digital Contact Tracing Slowed Covid-19 in East Asia." Harvard Business Review, April 15, 2020. Accessed November 7, 2020. https://hbr.org/2020/04/ how-digital-contact-tracing-slowed-covid-19-in-east-asia.

Hui, Yuk. 2016a. The Question Concerning Technology in China: An Essay in 
Cosmotechnics. Falmouth: Urbanomic.

- 2016b. On the Existence of Digital Objects. Minneapolis: University of Minnesota Press.

. (Xu Yu) 许显. 2017a. “Shumahua shidai keji he rewende qiji 数码化时 代科技和人文的契机 (Possibilities of Technology and Humanities in The Digital Era)." Wenhua congheng 2017 (5): 20-27.

. 2017b. "Cosmotechnics as Cosmopolitics." e-flux journal\# 86, November 8, 2017: 1-11. Accessed December 5, 2020. https:/www.e-flux.com/ journal/86/161887/cosmotechnics-as-cosmopolitics/.

——. (Xu Yu) 许煜. 2018. “Qi' yu 'dao': chao renleizhuyi weilaide yizhong huiying “器”与 ‘道”: 超人类主义未来的一种回应 (A Reply Regardgin the Future of Humanism)." Shehui kexue bao 2018 (6): 1-2.

—. 2019. "What Begins After the End of the Enlightenment?" e-flux journal\# 96, January 17, 2019: 1-10. Accessed November 13, 2020. https:// www.e-flux.com/journal/96/245507/what-begins-after-the-end-of-the-ewnlightenment/\#: :text=The\%20end\%20of\%20the\%20Enlightenment $\% 20$ has $\% 20$ to\%20begin,sensitivity $\% 20$ to\%20resolve $\% 20$ tensions $\% 20$ within $\% 20$ increasingly\%20isolated\%20groupings.

Jiang, Xinyan. 2002. "Zhang Dongsun: Pluralist Epistemology and Chinese Philosophy." In Contemporary Chinese Philosophy, edited by Cheng Chung-Ying, and Nicholas Bunnin, 57-81. Oxford: Blackwell Publishers.

Kempter Streib, Kathleen, and Victor L. Streib. 1978. "Social Control in Traditional China." International Journal of Comparative and Applied Criminal Justice 2 (2): 207-18, DOI: 10.1080/01924036.1978.9688661.

Kim, Tammy. 2020. "Audrey Tang on her "Conservative-Anarchist" Vision for Taiwan's Future." Rest of World: Reporting Global Tech Stories, September 29, 2020. Accessed December 12, 2020. https://restofworld.org/2020/ audrey-tang-the-conservative-anarchist/.

Kostka, Genia. 2019. "China's Social Credit Systems and Public Opinion: Explaining High Levels of Approval.” New Media and Society 21 (7): 1565-93.

Lanier, Jaron, and Glen Weyl. 2020. "AI Is an Ideology, Not a Technology." Wired, March 15, 2020. Accessed November 7,2020. https:/www.wired.com/story/ opinion-ai-is-an-ideology-not-a-technology/.

Leroi-Gourhan, André. 1945. Milieu et techniques. Paris: Albin Michel.

Li, Zehou, and Jane Cauvel. 2006. Four Essays on Aesthetics: Toward a Global View. Lanham: Lexington Books.

Li, Zehou 李澤厚. 2016. Renleixue lishi bentilun 人類學歷史本體論 (Anthropo-Historical Ontology). Qingdao: Qingdao chuban she.

Lunyu s.d. (The Analects). Chinese Text Project. Pre-Qin and Han. Accessed July 7, 2020. https://ctext.org/analects. 
Rockmore, Tom. 2019. “Hegel and Chinese Marxism.” Asian Studies 7 (1): 55-73. https://doi.org/10.4312/as.2019.7.1.55-73.

Rošker, Jana S. 2008. Searching for the Way: Theories of Knowledge in Pre-Modern and Modern China. Hong Kong: Chinese University Press.

—.2018. "Strukturna zveza zavesti ter zunanjega sveta v kitajski tradiciji." Asian Studies 6 (1):161-81.

-2021. Kriza kot nevarnost in upanje: etike pandemij, razcvet avtokracij in sanje o avtonomiji v transkulturni perspektivi. Ljubljana: Znanstvena založba FF.

Simodon, Gilbert. 1980. On the Mode of Existence of Technical Objects. Translated by Ninian Mellamphy. Oshawa: University of Ontario.

Stiegler, Bernard. 2016. "Foreword." In On the Existence of Digital Objects, author Yuk Hui, vii-xiv. Minneapolis: University of Minnesota Press.

Tian, Chenshan.2019. "Mao Zedong, Sinization of Marxism, and Traditional Chinese Thought Culture.” Asian Studies 7 (1): 13-37. https://doi.org/10.4312/ as.2019.7.1.13-37.

Zhang, Dongsun 張東荪. 1995. Lixing yu liangzhi-Zhang Dongsun wenxuan 理 性與良知 - 張東蓀文選 (Reason and Original Knowledge-Selected Works by Zhang Dongsun). Edited by Zhang Rulun. Shanghai: Yuandong chuban she. 